https://doi.org/10.15421/40280204

Article received 02.03.2018 p.

Article accepted 29.03.2018 p.

удк 630.453
ISSN 2519-2477 (online)

(c) (4)

@ Correspondence author

O. Yu. Andreieva

andreeva-lena15@ukr.net

О. Ю. Андреєва, І. В. Мартинчук

Житомирський національний агроекологічний університет, м. Житомир, Украйна

\title{
ЕКОНОМІЧНІ АСПЕКТИ ВИРУБУВАННЯ ДЕРЕВ, ЗАСЕЛЕНИХ СТОВБУРОВИМИ ШКІДНИКАМИ, У СОСНОВИХ ЛІСАХ ПОЛІССЯ
}

\begin{abstract}
Оцінено втрати внаслідок погіршення якості деревини сосни звичайної в осередках стовбурових шкідників у Поліссі. Встановлено, що короїди починають заселяти дерева у квітні, а у травні заселеність дерев у верхній частині стовбурів сягає $12 \%$, у середній частині стовбурів - 9\%. У червні заселеність дерев наростає через чорного соснового вусача та друге покоління верхівкового й шестизубчастого короїдів. У червні та серпні у верхній частині заселено 32 і 87 \% дерев, у середній 44 і $74 \%$, у нижній - 35 і 65 \% відповідно. Деревину дерев, заселених у квітні, оцінюють у червні третім сортом, а у вересні - як технологічну сировину. Встановлено, що деревина дерев, які всохли у 2016 р., а у вересні 2017 р. залишалися сухостоєм, придатна як технологічна сировина, а деревина зрубаних і залишених на землі дерев - як дрова. Визначено, що вартість деревини в осередках стовбурових шкідників зменшується в 1,71 раза або на 70,8 \% у випадку, якщо дерева, заселені у поточному році, залишити у лісі до кінця вересня. У разі вирубання та залишення заселених дерев на землі у лісі до кінця вересня наступного року вартість деревини зменшується у 2,42 раза або на 142,1 \%. Рішення стосовно вилучення дерев старого сухостою, які не заселяються фізіологічними стовбуровими шкідниками, для отримання деревини потрібно приймати 3 урахуванням екологічних і економічних аспектів.
\end{abstract}

Ключові слова: сосна звичайна (Pinus sylvestris); короїди; сезонна динаміка заселення дерев; ділова деревина.

Вступ. Останнім часом стан хвойних лісів погіршився у багатьох регіонах світу (Parker et al., 2006; Kramer et al., 2014; Kukhta et al., 2014; Hicke et al., 2016; Lieutier et al., 2016). На тлі зміни клімату, коливання рівня грунтових вод, антропогенного навантаження поширилися масові розмноження стовбурових шкідників і збудників хвороб, зокрема офіостомових грибів, які переносять ці комахи (Davydenko et al., 2014, 2017).

Встановлено, що у насадженнях сосни звичайної (Pinus sylvestris Linnaeus 1753) ДП "Житомирське ЛГ", осередки всихання приурочені до свіжого субору, чистих насаджень віком понад 70 років і переважно з низькою повнотою (Andreieva \& Zymaroyeva, 2016; Andreieva, 2017).

Життєздатні дерева сосни звичайної у регіоні заселяють найчастіше короїди (Curculionidae, Scolytinae) верхівковий Ips acuminatus (Gyllenhal, 1827) і шестизубчастий Ips sexdentatus (Boerner, 1767)), великий (Tomicus piniperda (Linnaeus, 1758) і малий T. minor (Hartig, 1834) соснові лубоїди, златка синя соснова (Phaenops cyanea: Buprestidae), вусачi (Cerambycidae) чорний сосновий (Monochamus galloprovincialis (Olivier, 1795)) та сірий довговусий (Acanthocinus aedilis (Linnaeus, 1758) (Andreieva, 2016). Ці види комах домінують в ослаблих соснових насадженнях багатьох регіонів Свропи (Fассоli et al., 2012; Lopez et al., 2012; Colombari et al., 2013), зокрема України (Meshkova et al., 2015a,b, 2017a,b; Meshkova, 2017). За частотою заселення дерев у біль- шості регіонів домінує верхівковий короїд, який надає перевагу гілкам і верхівкам, але за високої чисельності заселяє також ділянки стовбурів із перехідною корою (Meshkova et al., 2015a).

Стрімке поширення стовбурових шкідників і синяви у соснових лісах спричиняє погіршення не тільки санітарного стану насаджень, але і якості деревини, зокрема зменшення виходу ліквідної деревини (Volchenkova \& Zvyagintsev, 2013). У багатьох країнах доведено, що проведення вибіркових і суцільних санітарних рубок не призводить до зупинення процесів усихання соснових насаджень (Lindenmayer \& Noss, 2006; Faccoli et al., 2011; Montano et al., 2016; Mezei et al., 2017). Водночас у разі масового всихання лісів лісове господарство має "врятувати" деревину, доки вона не втратила цінності. Тому зарубіжні лісівники розрізняють санітарні рубки (sanitary felling - вилучення заселених дерев незабаром після їхнього заселення і до вильоту нового покоління жуків) та рубки "порятунку" (salvage logging) (Hernández-Hernández et al., 2017). Рубки "порятунку" зазвичай призначають після пожежі або вітровалу для отримання одержання деревини, яка в разі ії залишення на місці може бути зруйнована грибами та комахами i втрачена як продукція лісового господарства (Lindenmayer \& Noss, 2006). Водночас відзначено негативний вплив таких рубок, як і будь-яких інших рубок, на цикли поживних речовин і грунтоутворення, на структуру лісу та біорізноманіття (Lindenmayer \& Noss, 2006;

Інформація про авторів:

Андреєва Олена Юріївна, канд. с.-г. наук, доцент, доцент кафедри експлуатації лісових pecypciв. Email: andreeva-lena15@ukr.net Мартинчук Іван Володимирович, канд. екон. наук, доцент, проректор з науково-педагогічної роботи, соціального та гуманітарного розвитку. Email: martynchuk.ivan@gmail.com

Цитування за ДСтУ: Андреєва О. Ю., Мартинчук І. В. Економічні аспекти вирубування дерев, заселених стовбуровими шкідниками, у соснових лісах Полісся. Науковий вісник НлтУ України. 2018, т. 28, № 2. С. 31-36.

Citation APA: Andreieva, O. Yu., \& Martynchuk, I. V. (2018). Economic Aspects of Felling the Trees Colonized by Stem Pests in the Pine Stands of Polissya. Scientific Bulletin of UNFU, 28(2), 31-36. https://doi.org/10.15421/40280204 
Jonášová \& Prach, 2008).

Згідно $з$ нормативами (GOST 9463-88, 1988), за наявності синяви та неглибоких червоточин якість деревини знижується до III гатунку. У міру збільшення тривалості знаходження деревини у лісі в ній за невисокої відносної вологості утворюються глибокі бічні тріщини від усушки, а за високої розвиваються стовбурові комахи-руйнівники деревини та дереворуйнівні гриби, які охоплюють усю товщу заболоні. У разі інтенсивного розвитку заболонної гнилі деревина не може використовуватися навіть як дрова (Volchenkova \& Zvyagintsev, 2013).

Аналіз останніх досліджень та публікацій. Аналіз літературних джерел свідчить, що певною мірою загальмувати розвиток спалаху стовбурових шкідників може вчасне вилучення заселених дерев. Водночас у Поліссі ще не досліджували зміни якості деревини сосни в осередку всихання, спричиненого насамперед верхівковим короїдом, у разі вилучення заселених дерев у різні терміни.

Мета дослідження - оцінити втрати внаслідок погіршення якості деревини сосни звичайної в осередках стовбурових шкідників у Поліссі.

Матеріали та методи дослідження. Дослідження проведено у 2016-2017 рр. у лісовому фонді Державного підприємства "Житомирське лісове господарство" (ДП "Житомирське ЛГ") у свіжому субору $\left(\mathrm{B}_{2}\right)$ у насадженнях VII-VIII класів віку.

Упродовж вегетаційного періоду 2016 р. щомісяця аналізували заселеність заготовлених стовбурів сосни звичайної комахами та поширеність синяви у деревині. До аналізу брали життєздатні дерева III-IV категорій санітарного стану (сильно ослаблені та всихаючі) діаметром 26-30 см. Загалом у 2016 р. було проаналізовано 105 модельних дерев. Для порівняння стану деревини, в якій завершили розвиток стовбурові комахи, у вересні 2017 р. було проаналізовано додатково 15 дерев, які загинули у 2016 р., були зрубані та залишені у лісі, та 15 дерев старого сухостою.

Під час оглядання кожного дерева у 2016 та 2017 pp. визначали видовий склад стовбурових комах, які заселили сосни, загальноприйнятими в лісовій ентомології методами (Methodical recommendations, 2011). Зважаючи на відмінності вартості деревини, отримуваної 3 різних частин дерева, а також приуроченість окремих видів комах до заселення частин стовбура із грубою, перехідною й тонкою корою, у кожну дату обліку окремо обчислювали частки заселених комахами дерев у верхній, середній і нижній частинах стовбура. Під час оглядання поселень стовбурових комах також реєстрували поширеність синяви у деревині.

Розподіл об'єму стовбурів дерев сосни за розмірноякісними категоріями визначали за допомогою таблиць (Handbook on Forest Taxation, 2013). Під час розрахунків використано ціни на деревину за даними Житомирського ОУЛМГ на 2017 р. Погодні умови аналізували за даними метеостанції Житомир. Дати аналізу зміни якості деревини узгоджували з особливостями сезонного розвитку найпоширеніших стовбурових шкідників (Meshkova et al., 2015b). Описову статистику та дисперсійний аналіз здійснювали стандартними методами (Kozlov, 2014) за допомогою пакету програм MS Excel.

Результати дослідження. За багаторічними даними метеостанції Житомир, стійкий перехід температури повітря через $5^{\circ} \mathrm{C}$ відбувається 27 березня, а перехід че- рез $10^{\circ} \mathrm{C}-17$ квітня. Водночас за останні роки температура повітря навесні наростала швидше, і ці явища змістилися на більш ранні дати (рис. 1).

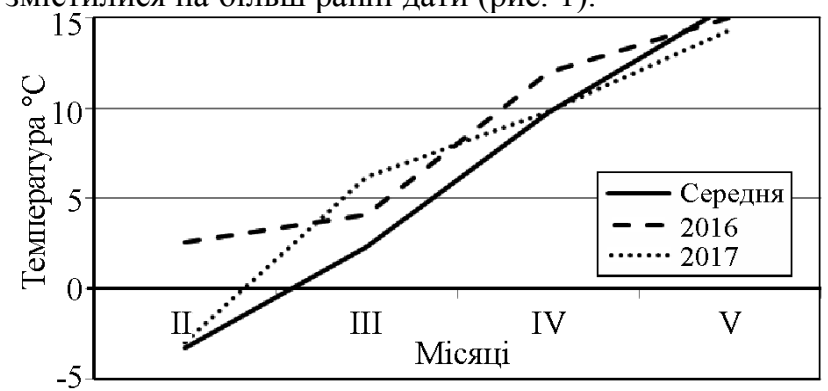

Рис. 1. Динаміка середньої місячної температури повітря у лютому - травні 2016 і 2017 pp. та за багаторічним даними метеостанції Житомир

Так, у 2016 р. стійкий перехід температури повітря через $5{ }^{\circ} \mathrm{C}$ відбувся на тиждень раніше, а у 2017 p. - на 15 днів раніше від середніх багаторічних дат (20 і 12 березня відповідно). Стійкий перехід температури повітря через $10^{\circ} \mathrm{C}$ відбувся у 2016 р. 8 квітня (на 9 днів раніше від багаторічних дат). Зазначені зміни темпів росту температури вплинули на терміни розмерзання грунту, прогрівання місць зимівлі стовбурових шкідників і їхнього вильоту з місць зимівлі. Зменшення річної кількості опадів у 2014-2016 pp. (564,2; 468,4 та 588,4 мм у 2014, 2015 і 2016 рр. відповідно) в 1,1-1,3 раза порівняно 3 багаторічними даними (619,3 мм) було однією 3 причин збільшення сприйнятливості дерев до заселення шкідливими комахами.

Аналіз модельних дерев у березні не виявив ознак їхнього заселення стовбуровими комахами (рис. 2). У квітні виявлено перші поселення верхівкового короїда, зосереджені переважно на гілках і верхівках, хоча на деяких деревах виявляли поселення також на ділянках стовбурів із перехідною корою.

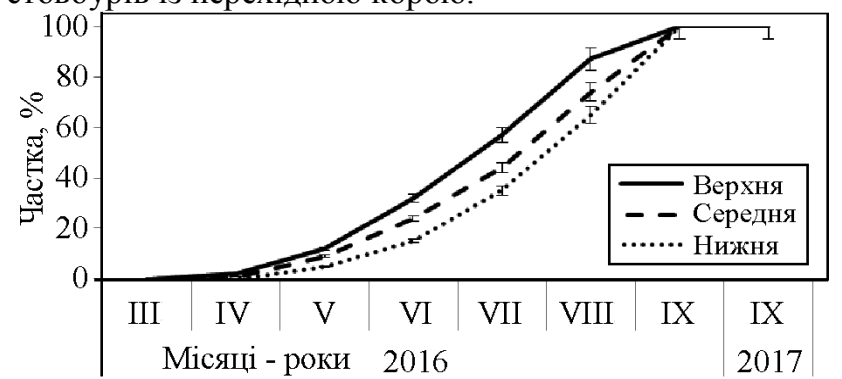

Рис. 2. Частка дерев, заселених стовбуровими шкідниками у верхній, середній і нижній частинах крон, у різні терміни

Загалом заселеність верхніх і середніх частин дерев (із тонкою та перехідною корою) у квітні становила 2 і $1 \%$ відповідно, а нижня частина дерев залишалася незаселеною.

У травні заселеність дерев стовбуровими шкідниками у верхній частині стовбурів зросла у 6 разів і сягала у середньому $12 \%$, а у середній частині стовбурів зросла у 9 разів і становила $9 \%$. Окрім верхівкового короїда, під тонкою корою було виявлено поселення малого соснового лубоїда, причому обидва види заселяли також частини стовбурів із перехідною корою. Нижню частину стовбурів заселяли великий сосновий лубоїд та шестизубчастий короїд із помітним переважанням останнього. Водночас заселеність комахами нижніх частин стовбурів у травні, як і у наступні місяці, була меншою, ніж верхніх і середніх частин (див. рис. 2). 
Майже одночасно з короїдами, що зимували, дерева заселяв сірий довговусий вусач, але він надавав перевагу більш ослабленим деревам, які вже заселили короїди. Чорний сосновий вусач заселяв дерева переважно у червні. Обидва види вусачів прокладали ходи переважно у частинах стовбурів із перехідною корою, але виявлялися також у верхніх і нижніх частинах дерев (під тонкою та грубою корою).

Після заселення дерев чорним сосновим вусачем заселеність наростала через друге покоління верхівкового та шестизубчастого короїдів. Водночас чисельність особин цих поколінь зазвичай є меншою, ніж весняного, i темпи збільшення заселеності дерев стовбуровими шкідниками уповільнилися. Так, у червні заселеність верхньої та середньої частин стовбурів зросла у 2,7 раза порівняно 3 травнем, у липні - в 1,8 раза порівняно 3 червнем, а у серпні - в 1,5-1,7 разу порівняно з липнем. Заселеність нижніх частин стовбурів також зростала повільніше у червні - вересні (див. рис. 2). Незважаючи на це, частка заселених дерев зростала. Частка дерев, заселених у верхній частині стовбурів, у червні становила $32 \%$, а у серпні - вже $87 \%$. Цей показник стосовно середньої частини стовбурів становив 44 і 74 \%, стосовно нижньої - 35 і 65 \% відповідно. На багатьох деревах були одночасно заселеними ділянки стовбурів із тонкою, перехідною та грубою корою. Під час розтинання ходів усіх стовбурових шкідників було виявлено ознаки синяви, яка також негативно впливала на якість деревини.

Розрахунки свідчать, що вихід деревини із 70-річних насаджень становитиме $564 \mathrm{~m}^{3}$, зокрема ділової $474 \mathrm{~m}^{3}$ (84\%). Вартість отриманої деревини сягатиме 553337,3 грн, зокрема ділової - 537947,3 грн (97\%) (табл. 1). Якщо дерева сосни у квітні інтенсивно заселив верхівковий короїд, а заселені дерева були вилучені санітарними рубками та вчасно вивезені 3 лісу, то якість деревини діаметром до $14 \mathrm{~cm}$ знижується до 3 сорту (табл. 2). Загальна вартість деревини з одного гектара становить у такому випадку 548858,3 грн, ділової - 533468,3 грн (97,2\%).

Табл. 1. Об'єм і вартість деревини, отриманої з 1 га 70-річних соснових насаджень за відсутності осередків стовбурових шкідників

\begin{tabular}{|c|c|c|c|c|c|}
\hline \multirow{2}{*}{ Сорт та вид деревини } & \multicolumn{5}{|c|}{ Об'єм, $\mathrm{m}^{3}$} \\
\hline & \multicolumn{4}{|c|}{ за категоріями крупності } & \multirow[b]{2}{*}{ Разом } \\
\hline Сорт & $\begin{array}{c}\text { груба } \\
(\varnothing \text { понад } 25 \text { см) }\end{array}$ & $\begin{array}{c}\text { середня } 1 \\
(\varnothing 20-25 \text { см })\end{array}$ & $\begin{array}{c}\text { середня } 2 \\
(\varnothing 14-19 \text { см })\end{array}$ & $\begin{array}{c}\text { дрібна } \\
(\varnothing 4-13 \text { см })\end{array}$ & \\
\hline 1 & 23 & 96 & 17 & - & 136 \\
\hline 2 & 28 & 197 & 45 & 28 & 298 \\
\hline 3 & 6 & 23 & 6 & 5 & 40 \\
\hline Разом ділова & 57 & 316 & 68 & 33 & 474 \\
\hline Техсировина & - & - & - & 6 & 6 \\
\hline Дрова & - & - & $\begin{array}{lll}- & & \\
\end{array}$ & 28 & 28 \\
\hline Відходи & 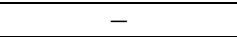 & $\begin{array}{lll}- & & \end{array}$ & $\begin{array}{lllll}- & & & & \\
\end{array}$ & $\begin{array}{llll}- & & & \end{array}$ & 56 \\
\hline Рaзoм & 57 & 316 & 68 & 67 & 564 \\
\hline \multirow{2}{*}{ Сорт та вид деревини } & \multicolumn{5}{|c|}{ Вартість, грн } \\
\hline & \multicolumn{4}{|c|}{ за категоріями крупності } & \multirow[b]{2}{*}{ Разом } \\
\hline Сорт & груба & середня 1 & середня 2 & $\begin{array}{c}\text { дрібна, техсировина } \\
\text { i дрова } \\
\end{array}$ & \\
\hline 1 & 32710,6 & 120960,0 & 17425,0 & 0,0 & 171095,6 \\
\hline 2 & 36212,4 & 233484,4 & 41040,0 & 14000,0 & 324736,8 \\
\hline 3 & 7272,6 & 26774,3 & 4818,0 & 3250,0 & 42114,9 \\
\hline Разом ділова & 76195,6 & 381218,7 & 63283,0 & 17250,0 & 537947,3 \\
\hline Техсировина & - & - & - & 2790,0 & 2790,0 \\
\hline Дрова & - & - & 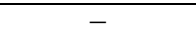 & 12600,0 & 12600,0 \\
\hline Рaзoм & 76195,6 & 381218,7 & 63283,0 & 32640,0 & 553337,3 \\
\hline
\end{tabular}

Табл. 2. Об'єм і вартість деревини, отриманої з 1 га 70-річних соснових насаджень у разі вилучення та вчасного вивезення заселених дерев у квітні

\begin{tabular}{|c|c|c|c|c|c|}
\hline \multirow{2}{*}{ Сорт та вид деревини } & \multicolumn{5}{|c|}{ Об'єм, $\mathrm{M}^{3}$} \\
\hline & \multicolumn{4}{|c|}{ за категоріями крупності } & \multirow[b]{2}{*}{ Разом } \\
\hline Сорт & $\begin{array}{c}\text { груба } \\
(\varnothing \text { понад } 25 \text { см })\end{array}$ & $\begin{array}{c}\text { середня } 1 \\
(\varnothing 20-25 \text { см })\end{array}$ & $\begin{array}{c}\text { середня } 2 \\
(\varnothing 14-19 \text { см })\end{array}$ & $\begin{array}{c}\text { дрібна } \\
(\varnothing 4-13 \text { см })\end{array}$ & \\
\hline 1 & 23 & 96 & - & - & 119 \\
\hline 2 & 28 & 197 & - & - & 225 \\
\hline 3 & 6 & 23 & 68 & 33 & 130 \\
\hline Разом ділова & 57 & 316 & 68 & 33 & 474 \\
\hline Техсировина & 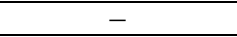 & $\begin{array}{ll}- \\
\end{array}$ & 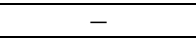 & 6 & 6 \\
\hline Дрова & - & - & - & 28 & 28 \\
\hline Відходи & - & - & - & - & 56 \\
\hline Разом & 57 & 316 & 68 & 68 & 564 \\
\hline \multirow{2}{*}{ Сорт та вид деревини } & \multicolumn{5}{|c|}{ Вартість, грн } \\
\hline & \multicolumn{4}{|c|}{ за категоріями крупності } & \multirow[b]{2}{*}{ Разом } \\
\hline Сорт & груба & середня 1 & середня 2 & $\begin{array}{c}\text { дрібна, техсировина i } \\
\text { дрова }\end{array}$ & \\
\hline 1 & 32710,6 & 120960,0 & - & - & 153670,6 \\
\hline 2 & 36212,4 & 233484,4 & - & - & 269696,8 \\
\hline 3 & 7272,6 & 26774,3 & 54604,0 & 21450,0 & 110100,9 \\
\hline Разом ділова & 76195,6 & 381218,7 & 54604,0 & 21450,0 & 533468,3 \\
\hline Техсировина & - & - & - & 2790,0 & 2790,0 \\
\hline Дрова & - & - & - & 12600,0 & 12600,0 \\
\hline Разом & 76195,6 & 381218,7 & 54604,0 & 36840,0 & 548858,3 \\
\hline
\end{tabular}

Науковий вісник НЛТУ України, 2018, т. 28, № 2 
Заселення агресивними стовбуровими комахами дерев сосни, погіршення їхнього санітарного стану та підвищення сприйнятливості до заселення іншими, менш агресивними комахами, триває у травні та червні. Поселення охоплюють усі частини стовбура, зокрема із грубою корою (див. рис. 2). У випадку, якщо заселені стовбуровими шкідниками сосни не вирубали й не вивезли або не захистили коруванням чи інсектицидами до кінця червня, вся груба та середня деревина може належати тільки до 3 сорту (табл. 3).

Загальна вартість отриманої з одного гектара деревини становитиме 528389,3 грн, зокрема ділової 512999,3 грн. На цей період якість деревини погіршується дуже мало, оскільки вусачі тільки починають заселяти дерева, а ходи короїдів $\epsilon$ поверхневими. Під корою та в деревині заселених дерев у цей період можна виявити практично всі стадії короїдів і личинок вусачів. Тому вилучення заселених дерев у червні за умови термінового вивезення, корування або захисту інсектицидами матиме значний оздоровчий ефект і зменшить ризик заселення інших сприйнятливих дерев.

Якщо заселену стовбуровими шкідниками деревину не вивезли до кінця вересня, то за період із початку вегетації під корою встигають завершити розвиток одне чи два покоління короїдів, а у червні дерева заселяє чорний сосновий вусач. Можливий виліт деяких особин сірого довговусого вусача, хоча певна частина популяції залишається на стадії личинки. За високої щільності популяцій цих комах дерево всихає та стає принадним для вусачів, які заселяють мертву деревину.

Фактично всі дерева, які були заселені наприкінці вересня, мали ходи стовбурових шкідників під тонкою, перехідною та грубою корою (див. рис. 2). Розрахунки свідчать, що вартість такої деревини становитиме 323998,3 м³/га (табл. 4).

Табл. 3. Об'єм і вартість деревини, отриманої з 1 га 70-річних соснових насаджень у разі залишення заселених дерев у лісі до кінця червня

\begin{tabular}{|c|c|c|c|c|c|}
\hline \multirow{2}{*}{ Сорт та вид деревини } & \multicolumn{5}{|c|}{ Об'єм, ${ }^{3}$} \\
\hline & \multicolumn{4}{|c|}{ за категоріями крупності } & \multirow[b]{2}{*}{ Разом } \\
\hline Сорт & $\begin{array}{c}\text { груба } \\
(\varnothing \text { понад } 25 \text { см) }\end{array}$ & $\begin{array}{c}\text { середня } 1 \\
(\varnothing 20-25 \mathrm{~cm})\end{array}$ & $\begin{array}{c}\text { середня } 2 \\
(\varnothing 14-19 \text { см })\end{array}$ & дрібна ( $\varnothing 4-13$ см) & \\
\hline 3 & 57 & 316 & 68 & 33 & 474 \\
\hline Разом ділова & 57 & 316 & 68 & 33 & 474 \\
\hline Техсировина & & & & 6 & 6 \\
\hline Дрова & & & & 28 & 28 \\
\hline Відходи & & & & & 56 \\
\hline Рaзом & 57 & 316 & 68 & 67 & 564 \\
\hline \multirow{2}{*}{ Сорт та вид деревини } & \multicolumn{5}{|c|}{ Вартість, грн } \\
\hline & \multicolumn{4}{|c|}{ за категоріями крупності } & \multirow[b]{2}{*}{ Разом } \\
\hline Сорт & груба & середня 1 & середня 2 & $\begin{array}{c}\text { дрібна, техсировина } \\
\text { i дрова }\end{array}$ & \\
\hline 3 & 69089,7 & 367855,6 & 54604,0 & 21450,0 & 512999,3 \\
\hline Разом ділова & 69089,7 & 367855,6 & 54604,0 & 21450,0 & 512999,3 \\
\hline Техсировина & - & - & - & 2790,0 & 2790,0 \\
\hline Дрова & - & - & - & 12600,0 & 12600,0 \\
\hline Pa3oM & 69089,7 & 367855,6 & 54604,0 & 36840,0 & 528389,3 \\
\hline
\end{tabular}

Табл. 4. Об'єм і вартість деревини, отриманої 31 га 70-річних соснових насаджень у разі залишення заселених дерев у лісі до кінця вересня

\begin{tabular}{|c|c|c|c|c|c|}
\hline \multirow{2}{*}{ Сорт та вид деревини } & \multicolumn{5}{|c|}{ Об'єм, $\mathrm{M}^{3}$} \\
\hline & \multicolumn{4}{|c|}{ за категоріями крупності } & \multirow[b]{2}{*}{ Разом } \\
\hline Сорт & $\begin{array}{c}\text { груба } \\
(\varnothing \text { понад } 25 \text { см) }\end{array}$ & $\begin{array}{c}\text { середня } 1 \\
(\varnothing 20-25 \mathrm{~cm})\end{array}$ & $\begin{array}{c}\text { середня } 2 \\
(\varnothing 14-19 \text { см })\end{array}$ & дрібна ( $\varnothing 4-13$ см) & \\
\hline Техсировина & 57 & 316 & 68 & 39 & 480 \\
\hline Дрова & - & - & - & 28 & 28 \\
\hline Відходи & 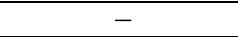 & - & - & 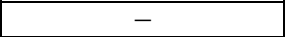 & 56 \\
\hline Рaзом & 57 & 316 & 68 & 67 & 564 \\
\hline \multirow{2}{*}{ Сорт та вид деревини } & \multicolumn{5}{|c|}{ Вартість, грн } \\
\hline & \multicolumn{4}{|c|}{ за категоріями крупності } & \multirow[b]{2}{*}{ Разом } \\
\hline Сорт & груба & середня 1 & середня 2 & $\begin{array}{c}\text { дрібна, техсировина } \\
\text { i дрова }\end{array}$ & \\
\hline Техсировина & 40726,5 & 212573,2 & 39963,6 & 18135,0 & 311398,3 \\
\hline Дрова & - & - & - & 12600,0 & 12600,0 \\
\hline Разом & 40726,5 & 212573,2 & 39963,6 & $\mathbf{3 0 7 3 5 , 0}$ & $\mathbf{3 2 3 9 9 8 , 3}$ \\
\hline
\end{tabular}

Останні розрахунки стосувалися деревини дерев, які всохли у 2016 р., а у вересні 2017 р. належали до VI категорії санітарного стану - "старого сухостою". Якщо дерева залишалися сухостоєм, їхня деревина була придатна як технологічна сировина, тобто якість їі практично не погіршилася порівняно з даними вересня 2016 р. Водночас, якщо дерева були зрубані та залишені на землі, їх заселяли комахируйнівники та дереворуйнівні гриби, і значна частина деревини ставала дров'яною вартістю 228600 грн/га.
Зведення даних стосовно зміни вартості деревини в осередках стовбурових шкідників у різні терміни свідчить, що цей показник відчутно зменшується (в 1,71 раза, або на 70,8 \%) тільки у разі, якщо заселені у поточному році дерева залишити у лісі до кінця вересня (табл. 5). Істотне (у 2,42 раза або на 142,1 \%) погіршення якості деревини сосни відбувається тільки у разі вирубання та залишення заселених дерев на землі у лісі до кінця вересня наступного року.

Обговорення отриманих результатів дослідження. У регіоні досліджень дерева сосни насамперед засе- 
ляє верхівковий короїд, який розмножується під корою гілок, а за високої чисельності - також під перехідною корою стовбура. Цей вид, а також шестизубчастий короїд, який заселяє переважно окоренкову частину стовбурів, мають не менше двох основних і сестринські покоління, причому чисельність першого покоління $\epsilon$ найбільшою. Жуки, які зимували, заселяють дерева поступово, а їхнє потомство вилітає у червні майже одночасно через високу температуру влітку.

Табл. 5. Зміна вартості деревини, отриманої з 1 га 70-річних соснових насаджень в осередку стовбурових шкідників у разі вилучення чи залишення заселених дерев у лісі у різні терміни

\begin{tabular}{|l|c|c|c|}
\hline \multicolumn{1}{|c|}{ Варіант } & \multirow{2}{*}{$\begin{array}{c}\text { Вартість } \\
\text { деревини, }\end{array}$} & \multicolumn{2}{|c|}{$\begin{array}{c}\text { Зниження } \\
\text { вартості }\end{array}$} \\
\cline { 4 - 5 } & грн/га & $\%$ & рази \\
\hline $\begin{array}{l}\text { Стовбурові шкідники відсутні } \\
\text { (базовий варіант) }\end{array}$ & 553337,3 & 0,0 & 1,00 \\
\hline $\begin{array}{l}\text { Вилучення та вчасне вивезення } \\
\text { заселених дерев у квітні }\end{array}$ & 548858,3 & $-0,8$ & 1,01 \\
\hline $\begin{array}{l}\text { Залишення заселених дерев у лісі } \\
\text { до кінця червня }\end{array}$ & 528389,3 & $-4,7$ & 1,05 \\
\hline $\begin{array}{l}\text { Залишення заселених дерев у лісі } \\
\text { до кінця вересня }\end{array}$ & 323998,3 & $-70,8$ & 1,71 \\
\hline $\begin{array}{l}\text { Вирубання та залишення заселених } \\
\text { дерев на землі у лісі до кінця верес- } \\
\text { ня наступного року }\end{array}$ & 228600 & $-142,1$ & 2,42 \\
\hline
\end{tabular}

Заселення дерев улітку відбувається за участі верхівкового короїда у верхній і середній частинах крон, шестизубчастого короїда - у нижній і середній частинах крон, а чорного соснового вусача - на більшій частині стовбурів, що створює умови для поширення синяви на всьому стовбурі. Санітарний стан заселених дерев погіршується впродовж 2-3 тижнів, що ускладнює вчасне їхнє виявлення та вилучення до вильоту потомства жуків.

Проведені дослідження свідчать, що до кінця червня за відсутності заходів захисту заселена деревина може належати тільки до 3 сорту. Водночас навіть у червні вилучення заселених дерев за умови термінового вивезення, корування або захисту інсектицидами матиме значний оздоровчий ефект і зменшить ризик заселення комахами сприйнятливих дерев. Загальна вартість деревини сосни відчутно зменшиться, якщо заселені у поточному році дерева залишити у лісі до кінця вересня, i таку деревину можна використовувати переважно як технологічну сировину. Якість деревини сухостою упродовж наступного після заселення року не погіршується, оскільки вона висихає та втрачає принадність для шкідливих організмів. Водночас зрубані й залишені на землі дерева заселяють комахи-руйнівники та дереворуйнівні гриби, i значна частина деревини стає дров'яною. Вилучати деревину, яку вже неможливо використовувати як дров'яну, недоцільно, оскільки в ній розвиваються гриби-антагоністи до патогенних видів, зокрема до збудника кореневої губки (Storozhenko, 2017).

Висновок стосовно темпів погіршення якості деревини заселених стовбуровими шкідниками дерев сосни не суперечить вимогам щодо необхідності вилучення заселених дерев до того, як нове покоління шкідників завершило розвиток під їхньою корою чи в деревині для запобігання збільшенню кількості заселених дерев і площі осередку всихання. Водночас дерева старого сухостою, які не заселяють фізіологічні стовбурові шкід- ники, не має сенсу вилучати для запобігання росту осередку, а рішення стосовно їхнього вилучення для отримання деревини потрібно приймати з урахуванням екологічних і економічних аспектів.

Висновки. У регіоні досліджень дерева сосни звичайної у квітні - травні заселяють верхівковий короїд, великий і малий соснові лубоїди, шестизубчастий короїд. У травні заселеність дерев стовбуровими шкідниками у верхній частині стовбурів сягає $12 \%$, у середній частині стовбурів - 9\%. У червні заселеність дерев наростає через чорного соснового вусача та друге покоління верхівкового й шестизубчастого короїдів. Частка дерев, заселених у верхній частині стовбурів, у червні та серпні становила 32 і $87 \%$, у середній частині - 44 і $74 \%$, у нижній - 35 і $65 \%$ відповідно.

Якість деревини дерев, заселених у квітні, у червні знижується до 3 сорту, а у вересні придатна як технологічна сировина. Деревина дерев, які всохли у 2016 р., а у вересні 2017 р. залишалися сухостоєм, придатна як технологічна сировина, а деревина зрубаних і залишених на землі дерев - як дрова. Вартість деревини в осередках стовбурових шкідників відчутно зменшується (в 1,71 раза, або на 70,8 \%) тільки у випадку, якщо заселені у поточному році дерева залишити у лісі до кінця вересня. У разі вирубання та залишення заселених дерев на землі у лісі до кінця вересня наступного року вартість деревини зменшується у 2,42 раза, або на 142,1 \%.

Вилучення дерев старого сухостою, які не заселяються фізіологічними стовбуровими шкідниками, не впливає на розвиток осередку. Рішення стосовно їхнього вилучення для отримання деревини потрібно приймати з урахуванням екологічних і економічних аспектів. Подальші дослідження мають бути спрямовані на розробку заходів із запобігання поширенню осередків усихання у соснових насадженнях.

\section{Перелік використаних джерел}

Andreieva, O. Y. (2016). Stovburovi shkidnyky v oseredkakh usykhannya sosnovykh nasadzhen DP "Zhytomyrske LH" Zhytomyrskoyi oblasti [Stem pests in the foci of pine stands decline in the State Enterprise "Zhytomyr Forest Economy" of Zhytomyr region]. The Bulletin of Kharkiv National Agrarian University. Series "Phytopathology and Entomology", 1-2, 3-9. [in Ukrainian].

Andreieva, O. Y. (2017) Sanitarnyy stan i rist sosnovykh nasadzhen v oseredkakh yikhnoho vsykhannya u DP "Zhytomyrske LH" [Health condition and growth of pine stands in the foci of their drying at the State Enterprise "Zhytomyr Forest Economy"]. Naukovi chytannya - 2017, (pp. 3-7). Zhytomyr: Vyd-vo "Zhytomyrskyy natsional'nyy ahroekolohichnyy universytet". [in Ukrainian)].

Andreieva, O. Y., Zymaroyeva, A. A. (2016). Osoblyvosti poshyrennya mikozu sosny zvychaynoyi u lisovykh nasadzhennyakh Zhytomyrskoho Polissya. [Peculiarities of spread of Scots pine mycosis in the forest stands Zhytomyr Polissya]. Naukovi chytannya - 2016, (pp. 125-129). Zhytomyr: Vyd-vo "Zhytomyrskyy natsionalnyy ahroekolohichnyy universytet". [in Ukrainian].

GOST 9463-88. (1988). Lesomaterialy kruglyye khvoynykh porod. Tekhnicheskiye usloviya. [Round timber of coniferous species. Specifications: GOST 9463-88]. [Vved. 1991-01-01]. Moscow: IPK Izd-vo standartov, 8. (Mezhgosudarstvennyy standart) [(Interstate Standard]. [in Russian].

Kashpor, S. M., \& Strochinsky, A. A. (Ed.) (2013). Lisotaksatsiynyy dovidnyk [Handbook on Forest Taxation]. Kyiv: Vyd. dim "Vinnichenko". [in Ukrainian].

Kozlov, M. V. (2014). Planirovaniye ekologicheskikh issledovaniy [Planning of ecological researches]. Moscow: Tovarishchestvo na- 
uchnykh izdaniy KMK [Moscow: Association of Scientific Publications KMK]. [in Russian].

Kukhta, V. N., Blintsov, A. I., \& Sazonov, A. A. (2014). Koroyedy yeli yevropeyskoy i meropriyatiya po regulirovaniyu ikh chislennosti [Bark beetles of Norway spruce and measures to regulate their population]. Minsk: BSTU. [in Russian].

Meshkova, V. L. (2011). Metodychni rekomendatsiyi shchodo obstezhennya oseredkiv stovburovykh shkidnykiv lisu [Methodical recommendations for survey of forest stem pest foci]. Kharkiv: URIFFM. 27 pp. [in Ukrainian].

Meshkova, V. L., Kochetova, A. I., \& Zinchenko, O. V. (2015a). Verkhivkovyy koroyid Ips acuminatus (Gyllenhal, 1827): Insecta: Coleoptera: Scolytinae u Pivnichno-Skhidnomu Stepu Ukrayiny [The pine engraver beetle Ips acuminatus (Gyllenhal, 1827) (Coleoptera: Curculionidae: Scolytinae) in the NorthEastern Steppe of Ukraine]. The Kharkov Entomol. Soc. Gaz., XXIII, 2, 64-69. [in Ukrainian].

Meshkova, V. L., Zinchenko, O. V., Skrylnik, Yu. Ye., \& Aristova, A. I. (2015b) Sroki razvitija stvolovyh vreditelej sosny v Levobe- rezhnoj Ukraine [The dates of development of pine stem pests in the Left-bank Ukraine]. Izvestiya Sankt-Peterburgskoy lesotekhnicheskoy akademii [Bulletin of the St. Petersburg Academy of Forestry], 211, 59-67. [in Russian].

Storozhenko, V. G. (2017). Gribnaya biotrofnaya derevorazrushayushchaya biota $\mathrm{v}$ lesnykh ekosistemakh yevropeyskoy Rossii [Fungal biotrophic wood-destroying biota in forest ecosystems of European Russia]. Ul'yanovskiy mediko-biologicheskiy zhurnal [Ulyanovsk Medical Biological Journal], 1, 147-154. https://doi.org/10.23648/UMBJ.2017.25.5256. [in Russian].

Volchenkova, G. A., \& Zvyagintsev, V. B. (2013). Degradatsiya kachestva drevesiny sukhostoynykh derev'yev sosny v ochagakh kornevoy gubki [Degradation of wood quality of dead pine trees in the root rot foci]. Sovremennoye sostoyaniye $i$ perspektivy okhrany $i$ zashchity lesov $v$ sisteme ustoychivogo razvitiya: materialy Mezhdunar. nauch.-prakt. konf. [Current state and perspectives of forest protection in the system of sustainable development: materials of the Intern. scientific-practical. conf.], (pp. 9-11). Gomel'. [in Russian].

Е. Ю. Андреева, И. В. Мартынчук

Житомирский национальный агроэкологический университет, г. Житомир, Украина

\section{ЭКОНОМИЧЕСКИЕ АСПЕКТЫ ВЫРУБКИ ДЕРЕВЬЕВ, ЗАСЕЛЕННЫХ СТВОЛОВЫМИ ВРЕДИТЕЛЯМИ, В СОСНОВЫХ ЛЕСАХ ПОЛЕСЬЯ}

Оценены потери вследствие ухудшения качества древесины сосны обыкновенной в очагах стволовых вредителей в Полесье. Установлено, что короеды начинают заселять деревья в апреле, а в мае заселенность деревьев в верхней части стволов составляет $12 \%$, в средней - $9 \%$. В июне заселенность деревьев нарастает из-за черного соснового усача и второго поколения вершинного и шести зубчатого короедов. В июне и августе в верхней части заселено 32 и $87 \%$ деревьев, в средней - 44 и $74 \%$, в нижней - 35 и $65 \%$ соответственно. Древесина деревьев, заселенных в апреле, оценивается в июне третьим сортом, а в сентябре - как технологическое сырье. Установлено, что древесина деревьев, усохших в 2016 г. и оставленных до сентября 2017 г. сухостоем, пригодна как технологическое сырье, а древесина срубленных и оставленных на земле деревьев - как дрова. Установлено, что стоимость древесины в очагах стволовых вредителей снижается в 1,71 раза или на 70,8 \% в случае, если деревья, заселенные в текущем году, оставлять в лесу до конца сентября. В случае, если срубленные деревья оставлены на земле в лесу до конца сентября следующего года стоимость древесины уменьшается в 2,42 раза или на $142,1 \%$. Решение относительно удаления с целью получения древесины деревьев старого сухостоя, не заселяемых физиологическими стволовыми вредителями, следует принимать с учетом экологических и экономических аспектов.

Ключевые слова: сосна обыкновенная (Pinus sylvestris); короеды; сезонная динамика заселения деревьев; деловая древесина.

O. Yu. Andreieva, I. V. Martynchuk

Zhytomyr National Agroecological University, Zhytomyr, Ukraine

\section{ECONOMIC ASPECTS OF FELLING THE TREES COLONIZED BY STEM PESTS IN THE PINE STANDS OF POLISSYA}

Recently, the health of coniferous forests has worsened in many regions as a result of climate change and anthropogenic loading, which contributed to the spread of stem insects and associated pathogens. Ips acuminatus is the dominant species, colonizing the upper part of stem with the least valuable timber. However, such trees quickly become susceptible to colonization by less aggressive insect species. The purpose of our research was to estimate the losses caused by deterioration of Scots pine timber quality in the focus of stem pests in Polissya. During the growing season in 2016, the spread of stem pests and blue-stain fungi in harvested pines was analysed monthly, particularly in the upper, middle and lower parts of a tree (105 trees in general). In September 2017, additionally 15 standing and 15 felled trees were analysed, which died previous year and were left in the forest. Research showed that bark beetles began colonizing pine trees in April. In May their occurrence in the upper and middle part of stem was 12 and $9 \%$ respectively. In June tree colonization increased due to Monochamus galloprovincialis and the second generation of Ips acuminatus and Ips sexdentatus. In June and August $32 \%$ and $87 \%$ trees were colonized in upper part, $44 \%$ and $74 \%$ in middle part, and $35 \%$ and $65 \%$ in lower part of stem respectively. The timber of trees colonized in April could be estimated in June as the third grade and in September as technological raw materials. The timber of trees died in 2016 and left standing was suitable as technological raw materials in September 2017. The timber of felled trees laying on the soil surface after such period was suitable as firewood. It has been calculated that the cost of timber in the focus of stem pests reduced for one year in 1.71 times, or by $70.8 \%$ if dead standing trees were left in the forest until the end of September 2017. The cost of timber of felled trees laying on the soil surface after such period reduced in 2.42 times, or by $142.1 \%$.

Keywords: Scots pine (Pinus sylvestris); bark beetles; seasonal dynamics of tree colonization; commercial timber. 